\section{Sakharov criticizes Soviet academy}

\section{London}

ACADEmician Andrei Sakharov last week publicly reproached the Soviet Academy of Sciences for failing to support him during his seven-year exile in Gor'kii. Members of the academy, Sakharov said, had "spread lies" about him and his wife and their wellbeing. Furthermore, in 1983, three members of the academy had published an article about him which was, he said, an "outright provocation".

Sakharov said that he hoped that the new policies of glasnost' (openness) and perestroika (restructuring) would lead the Academy to "participate in the worldwide struggle of scientists for the liberation of prisoners of conscience"; and criticized restrictions on place of residence and freedom to travel.

Sakharov was speaking at the French Embassy in Moscow, at a ceremony conferring on him honorary membership of the French Academy of Sciences. Sakharov had not been given permission to go to Paris, and he criticized the Academy for refusing to co-organize a Franco-Soviet colloquium to mark the event. Vera Rich Europeans lose in superconductivity

\section{London}

European scientists, anxious not to be left behind in the international race to develop the new high-temperature superconductors, are urging the European Community (EC) to begin a coordinated research effort in both the theory and applications of the new ceramics. This request emerged from a recent meeting in Genoa, organized by the Community, at which progress and prospects for the future were reviewed by 500 scientists representing institutions throughout countries in the EC and the European Free Trade Association (EFTA). As at the Berkeley meeting two weeks ago (see Nature 328,$14 ; 1987$ ), it was clear that despite the man-hours devoted to superconductor research, knowledge of the physical characteristics of the ceramic oxides is in its infancy; present research consists largely of fact-gathering.

The scientific community would like to see specific research programmes aimed at finding new materials, elucidating their properties, and working towards applications in both electronics and electrical engineering. In a move that echoes recent action by the US Department of Energy (see Nature 327, 356; 1987), it was also recommended that the Community should set up an information network and database to enable researchers to harness their efforts more effectively. David Lindley

\title{
European research programme at heart of budget row
}

London

THE budget for the five-year European research and development programme, Framework, has once more failed to gain approval from the 12 member states but instead has found itself at the heart of a bitter conflict which has isolated the United Kingdom from the rest of Europe.

Europe's scientific community had hoped that the two-day summit in Brussels last week would sanction the $£ 4,500$ million needed to support joint research programmes in the European Economic Community (EEC), designed for projects in information technology, biotechnology, AIDS and cancer, among others.

But even before the leaders formally meet, there were signs that conflict was inevitable and that the science budget

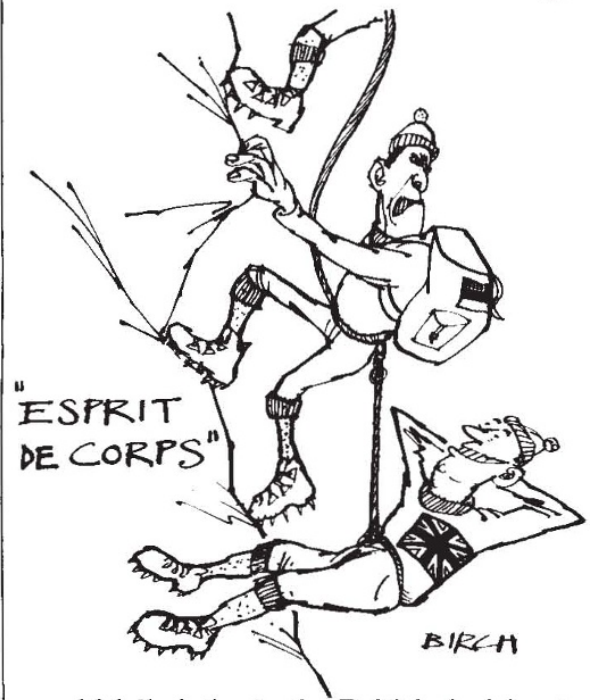

would fall victim to the British decision to veto approval of the total EEC budget for the coming year unless major reforms were forthcoming.

At the heart of the conflict is Prime Minister Margaret Thatcher's view that much of the EEC budget is mis-spent and that too much - now 70 per cent - is used to subsidize the Community's farming, a policy that greatly benefits France.

The political bartering of France and Germany was much in evidence on the evening before the summit, and even at breakfast-time on the first day, when meetings were supervised by Chancellor Helmut Kohl of West Germany and President François Mitterrand of France, in an attempt to find an unofficial solution. While Britain has shown a marked reluctance, since the end of last year, to approve the new science budget $-3,000$ research jobs in information technology alone are said to be under threat if early approval is not given - the latest conflict could mean another six months at least before the 12 states have an opportunity to agree.
The conflict and renewed veto of the research and development budget has surprised many in the UK high-technology industries who were convinced that the third administration of Thatcher's government would approve the research and development budget without question. Such confidence seemed to be confirmed by the sacking of the previous information technology minister Geoffrey Pattie - a new team has been installed at the Department of Trade and Industry (DTI) led by Lord Young, a 'political heavyweight' and a confidant of the Prime Minister.

Since last November, the EEC has been threatening to drop the joint research project unless the member states could agree. Nine months later, it has neither dropped the projects nor approved the necessary increased spending. The information technology programme, Esprit, is now six months behind schedule and other major projects are now expected to suffer.

Britain's justification for vetoing the proposed budget is complex. Apart from its dislike of the CAP and the methods adopted for the management and the approval of research programmes, it is at odds with the needs in aid and financial relief of many member states, particularly those from the poor and less industrially developed countries. Thatcher's government, which has been notorious in its opposition to increased public expenditure, is faced with a Community that now seeks to be substantially more than a free marketplace for its members' produce and products. Those ambitions now extend to increasing substantially regional development grants.

On her return from Brussels, Thatcher agreed that spending could continue at its present level - the annual research and development budget is 1,040 million ECU (European Currency Units, $1=£ 0.71$ ) and in the long term her government would seek better control procedures on spending "by seeing they are translated into regulations before we consider any increase in spending". Bill Johnstone - Officials at the British National Space Centre (BNSC) have met Lord Young, and are confident that the government will respond positively to their proposals by the end of this month. Unless it receives approval then, claims BNSC, Britain will be unable to take part in the immediate research projects planned by the European Space Agency. These include programmes for the Ariane space rocket and the Hermes space plane.

This is the first issue of Nature to be printed in Japan. 